\title{
Gaziantep ilinde keçi işletmelerinden toplanan çiğ süt örneklerinde somatik hücre sayısının AB kriterleri bakımından değerlendirilmesi
}

\author{
Evaluation of somatic cell count in raw milk samples collected from goat farms in \\ Gaziantep province for EU norms
}

\author{
Ali KAYGISIZ ${ }^{1 *}$ iD \\ ${ }^{1}$ Kahramanmaraş Sütçü İmam Üniv. Ziraat Fak. Zootekni Böl. Kahramanmaraş
}

To cite this article:

Kaygısız, A (2020). Gaziantep ilinde keçi işletmelerinden toplanan çiğ süt örneklerinde somatik hücre sayısının $A B$ kriterleri bakımından değerlendirilmesi. Harran Tarım ve Gıda Bilimleri Dergisi, 24(4): 484-489.

DOI:10.29050/harranziraat.801225

Address for Correspondence: Ali KAYGISIZ

e-mail:

alikaygisiz@ksu.edu.tr

\section{Received Date:}

28.09.2020

Accepted Date:

10.11.2020

(C) Copyright 2018 by Harran University Faculty of Agriculture. Available on-line at www.dergipark.gov.tr/harranziraat

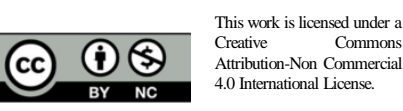

öz

Bu çalışmada, Gaziantep ilinde toplanan keçi sütlerindeki tank somatik hücre sayısının (SHS) yasal düzenlemeler açısından değerlendirilmesi amaçlanmıştır. Araştırma kapsamındaki Gaziantep İli Damızlık Koyun Keçi Yetiştiricileri Birliği süt toplama merkezine getirilen süt örneklerinde somatik hücre sayımları yapılmıştır. Elde edilen süt örneklerinin SHS ölçümleri DCC (DeLaval Somatik Hücre Ölçüm Cihazı) ile yapılmıştır. Tank sütü somatik hücre sayısına ayların etkisi çok önemli $(P<0.01)$, işletme etkisi ise önemli $(P<0.05)$ bulunmuştur. Tank sütü somatik hücre sayısına ait genel, geometrik ve Log10 SHS değerleri sırasıyla $781437.50 \pm$ 39829 hücre $^{-\mathrm{ml}}, 728894.37$ hücre $^{-\mathrm{ml}}$ ve $5.849 \pm 0.0199$ hücre ${ }^{-\mathrm{ml}}$ olarak hesaplanmıştır. Çalışma sonuçlarına göre işletmelerden toplanan tank sütü somatik hücre sayılarının \% 95'inin $A B$ otoriteleri tarafından önerilen değerden düşük olduğu tesbit edilmiştir.

Anahtar Kelimeler: Tank sütü somatik hücre sayısı, Keçi, Gaziantep

\section{ABSTRACT}

In this study, tank somatic cell counts of goat milks was evaluated according to legal norms. Somatic cell counts were determined in the milk samples brought to the milk collection center of Gaziantep Province Breeding Sheep and Goat Breeders Union within the scope of the research. The effect of months on tank milk somatic cells counts was found to be higly significant $(P<0.01)$, and the herd effect was found to be significant $(P<0.05)$. Generaly, geometric and Log10 SHS values of tank milk somatic cell count were calculated as $781437.50 \pm 39829$ cells $^{-\mathrm{ml}}, 728894.37$ cells $^{-\mathrm{ml}}$ and $5.849 \pm 0.0199$ cells $^{-\mathrm{ml}}$, respectively. Based on the current the study, it was determined that $95 \%$ of the tank milk somatic cell numbers collected from the enterprises were lower than the values suggested by the EU authorities.

Key Words: Tank milk somatic cell count, Goat, Gaziantep

\section{Giriş}

Somatik hücre sayısı (SHS), çiğ sütte kalitenin belirlenmesinde kullanılan en önemli kriterlerden biridir. SHS değerinde meydana gelen artışlar, klinik ve subklinik mastitis gibi önemli hastalıkların da net bir göstergesidir. Sütte SHS'nin artması, süt veriminde azalmaya neden olmakta, süt kalitesini olumsuz yönde etkilemekte, sütün ürünlere işlenmesinde büyük sorunlara neden olmaktadır. Özellikle koyun ve keçi populasyonlarında yapılan çalışmalarda, SHS artışının süt veriminde azalmaya neden olduğu (Raynal-Ljutovac ve ark., 2007; Koop ve ark., 2010; Arias ve ark., 2012; Barrón-Bravo ve ark., 2013; Sutera ve ark., 2018; Mehdit ve ark., 2019; Sandrucci ve ark., 2019; Paschino ve ark., 2019), süt kompozisyonunu etkilediğini (Sutera ve ark., 2018) ve bunun da peynir yapım yeteneğini 
azalttığı (Marcinkoniene ve Ciprovica, 2020) bildirilmiştir.

Keçi sütündeki SHS'nın değerlendirilmesinde hayvan faktörünün yanısıra ırk ve genetik özellikler, laktasyon ayı, laktasyon sırası, östrus, oğlaklama mevsimi ve kuru dönemin uzunluğu gibi gibi birçok faktörün gözönüne alınması gerektiği bildirilmiştir (Paape ve ark., 2007; Raynal-Ljutovac ve ark., 2007; Rupp ve ark., 2011; Barrón-Bravo ve ark., 2013; Stuhr ve ark., 2013).

Türk Gıda Kodeksi İçme Sütleri Tebliğinde koyun ve keçi sütü için herhangi bir SHS sınırı belirlenmemiştir (Anonim, 2019a). Avrupa Birliği (AB), SHS üst sınırını tüm türler için 400.000 hücreml (Anonim, 1992), olarak belirlemiştir. ABD'de SHS üst sınırı keçi sütü için 1.500 .000 hücre ${ }^{-\mathrm{ml}}$, koyun ve sığır sütü için ise 750.000 hücre-ml olarak belirlenmiştir (Anonim, 2019b). Diğer yandan ABD'de tank sütü SHS için yasal sınır keçide 1.000.000 hücre ${ }^{-m l}$, koyunda ise 750.000 hücre $^{-}$ ml'dir (Paape ve ark., 2001). Uluslararası Küçükbaş Ruminantlar süt ve somatik hücre sempozyumunda (Barbosa ve ark., 1994), AB otoriteleri keçi ve koyun tank sütü için SHS yasal sınırının $1.5 \times 10^{6}$ hücre-ml' den düşük olmaması gerektiğini önermişlerdir.

Keçi sütündeki SHS için farklı eşik seviyeleri önerilmiş olmakla beraber meme enfeksiyonlarının oluşması için öngörülen SHS eşik değerleri oldukça değişkendir. Zira, sağııkı keçilerden elde edilen sütün SHS'sı, enfekte olmamış inek ve koyunların sütünde gözlemlenen SHS'den daha yüksektir (Persson ve Olofsson, 2011; Souza ve ark., 2012). Sığırlarda merokrin olan süt salgı sisteminin, keçilerde apokrin olması ve keçide sitoplazmik parçacıklarında sütte bulunmasından dolayı keçi sütünde SHS daha yüksek olmaktadır (Griffiths, 2010).

Bu çalışmada, Gaziantep ili Damızlık Koyun Keçi Yetiştiricileri Birliği süt toplama merkezine getirilen keçi sütü örneklerinde somatik hücre sayımları yapılmış, elde edilen sütlerin uluslararası standartlara uygunluğu ortaya konmuştur.

\section{Materyal ve Metod}

\section{Materyal}

Araştırma kapsamındaki Gaziantep ili Damızlık Koyun Keçi Yetiştiricileri Birliği süt toplama merkezine getirilen keçi sütü örneklerinde somatik hücre sayımları yapılmıştır. Süt örneklerini getiren yetiştiricilerle bire-bir yapılan görüşmelerde işletmelerde sürü büyüklüğünün $120-650$ baş arasında değiştiği, tüm sürülerde sağımların elle yapıldığı, her bir yetiştiricinin kendi sürüsünü mer'ada otlattığı ve mera dönüşü ise hayvanlara bir miktar kesif yem verildiği bilgisi alınmıştır.

\section{Metod}

Elde edilen süt örneklerinin SHS ölçümleri DCC (DeLaval Somatik Hücre Ölçüm Cihazı, DeLaval Group, İsveç) ile yapılmıştır. De Laval sayım kiti içerisine birkaç damla süt örneği çekildikten sonra, süt yüklü kaset DeLaval hücre sayıcıya yerleştirilerek ölçüm değeri belirlenmiştir. DCC cihazı, Propidium lodide ile boyanmış somatik hücreleri saymaktadır. Ölçümler bir dakikadan daha kısa süre içerisinde hücre sayım ekranında görülmektedir (Gonzalo ve ark., 2006; Berry ve Broughan, 2007).

\section{istatistik analiz}

Somatik hücre sayısına işletme ve ay etkisi varyans analizi ile araştırılmıştır. Kullanılan matematik model; $Y_{i j k}=\mu+a_{i}+b_{j}+e_{i j k}$ şeklinde olup bu formülde yer alan terimlerden; $\mu=$ populasyon ortalamasını, $a_{i}=i$. işletme etki miktarını, $b_{j}=j$. ay etki miktarını, $e_{i j k}=$ normal, bağımsız şansa bağı hatayı temsil etmektedir. Farklı alt grupların (aylar) ortalamalarının karşılaştırılmasında ise Duncan çoklu karşılaştırma testi kullanılmıştır. Variyans analizleri ve çoklu karşılaştırma testleri SAS paket programı ile yapılmıştır (Orhan ve ark., 2004). Yapılan ön analizlerde SHS değerlerinin normal dağılım gösterdiği tespit edilmiştir. Bununla birlikte $\log _{10}$ tabanına göre transformasyon uygulanan SHS değerleri de hesaplanmıştır. Ayrıca işletmeler bazında toplanan süt örneklerinin geometrik ortalamaları da hesaplanmıştır. 


\section{Bulgular ve Tartışma}

Somatik hücre sayılarının ölçüm yapılan aylara göre değişimi Tablo 1'de verilmiştir. Bu çalışmada elde edilen genel SHS değeri (781437.50 hücre ${ }^{-m l}$ ), Marcinkoniene ve Ciprovica (2020) tarafından Yerli Latvian, Saanen ve melez keçileri için bildirilen $1.514 \pm 1.260 * 10^{3}$ hücre ${ }^{-m l}, 1.100 \pm 879 * 10^{3}$ hücre $^{-m l}$ ve $1.559 \pm 1.988 * 10^{3}$ hücre ${ }^{-m l}$ değerlerinden, Luengo ve ark. (2001) tarafından Murciano-Granadina keçilerinde tank sütü için bildirilen 973.000 hücre ${ }^{-m l}$ değerlerinden daha düşük bulunmuştur.
Yine bu çalışmada elde edilen geometrik SHS değeri (728894 hücre ${ }^{-m l}$ ), Luengo ve ark., (1999) ve Droke ve ark., (1993) tarafından bildirilen değerlerden daha düşük, $\log _{10}$ SHS değeri (5.848 hücre-ml) ise, Sandrucci ve ark.,(2019) tarafından bildirilen 5.8 hücre ${ }^{-m l}$ ve Corrales (2004) tarafından bildirilen 5.89 hücre ${ }^{-\mathrm{ml}}$ değerlerine benzer, Droke ve ark.,(1993) tarafından bildirilen 6.12 hücre-ml değerinden düşük, Margatho ve ark.,(2018) tarafından Serrana keçilerinde bildirilen 3.39 \pm 0.19 hücre-ml değerinden ise yüksek bulunmuştur.

Tablo 1. Somatik hücre sayısına etkili faktörler, ortalamalar, variyans analizi, önemlilik ve çoklu karşılaştırma test sonuçları

Table 1. Means for tank milk somatic cell count, factors affecting, analysis of variance, significance and multiple comparison test results

\begin{tabular}{|c|c|c|c|}
\hline & & $\begin{array}{l}\text { Somatik Hücre Sayısı } X \pm S x \\
\text { Somatic cell counts } X \pm S X\end{array}$ & $\begin{array}{l}\log _{10} \mathrm{SHS} \\
\quad \mathrm{X} \pm \mathrm{Sx}\end{array}$ \\
\hline Genel (General) & 96 & $781437.50 \pm 39829$ & $5.849 \pm 0.0199$ \\
\hline İşletmeler (Herd) & & $*$ & $*$ \\
\hline Aylar (Month) & & $* *$ & $* *$ \\
\hline Mayıs (May) & 41 & $626634.15 \pm 57873.224 \quad$ a & $5.760 \pm 0.0284 \mathrm{a}$ \\
\hline Haziran (June) & 20 & $952550.00 \pm 82861.846 \quad b$ & $5.933 \pm 0.0406 b$ \\
\hline Temmuz (July) & 16 & $891937.50 \pm 92642.361 b$ & $5.918 \pm 0.0454 b$ \\
\hline Ağustos (August) & 19 & $842315.79 \pm 85014.461 \mathrm{ab}$ & $5.896 \pm 0.0417 b$ \\
\hline
\end{tabular}

*;P<0.05, **;P<0.01, a,b; Aynı sütunda farklı harflerle gösterilen ortalamalar arasındaki farklar önemlidir.

SHS'ye ölçüm yapılan ayların etkisi çok önemli $(P<0.01)$ bulunmuştur. En düşük SHS değeri 626634 hücre ${ }^{-m l}$ (Log $\log _{10}$ SHS 5.760) ile Mayıs ayında en yüksek SHS değeri ise 952550 ( $\log _{10}$ SHS 5.933) hücre $^{-m l}$ ile Haziran ayında elde edilmiştir (Şekil 1).

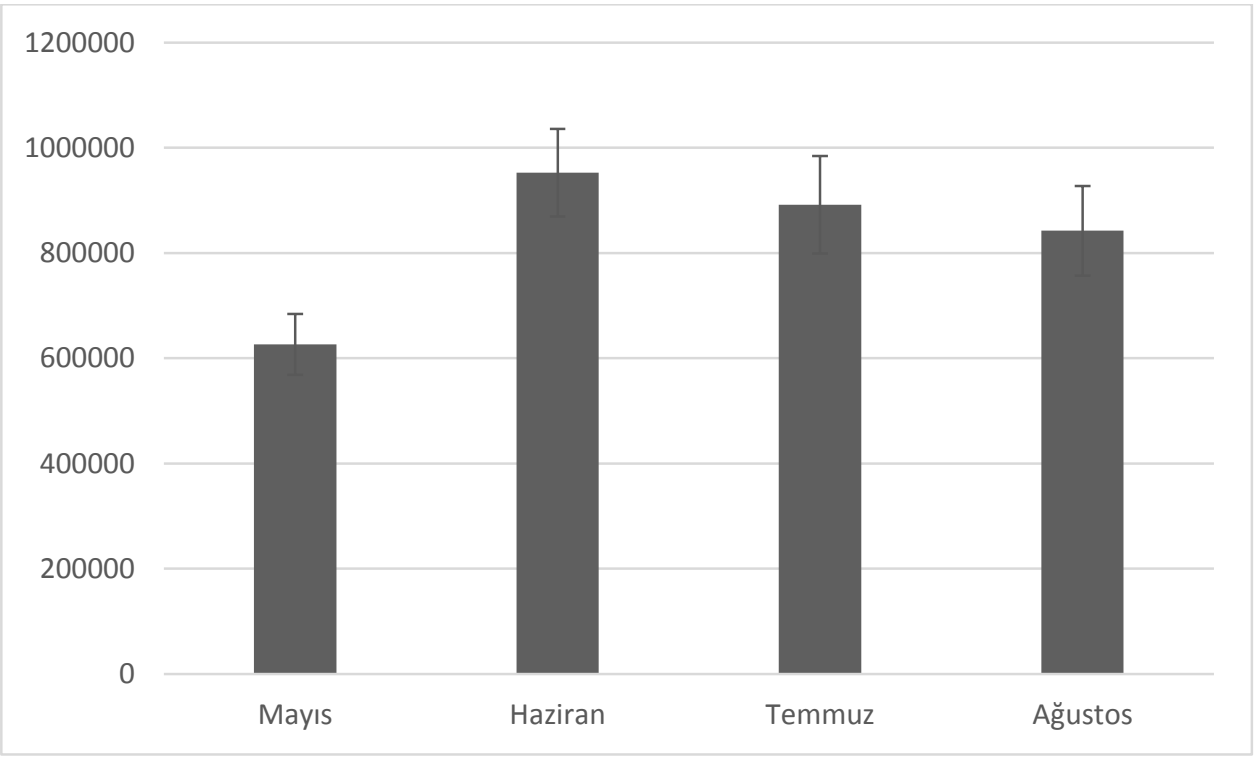

Şekil 1. Aylara göre somatik hücre sayıları

Figure 1 . Somatic cell count by months

Tüm dönemlere ait genel ortalama ise 781437.50 hücre-ml ( $\log _{10}$ SHS 5.849) olarak bulunmuştur. $\mathrm{Bu}$ araştırma bulgularına benzer olarak, Margatho ve ark., (2018), Sandrucci ve ark., (2019) laktasyon sonunda SHS'nın daha yüksek olduğunu bildirmişlerdir. Diğer yandan, SHS'na 
ölçüm yapılan ayların etkisinin önemli bulunmuş olması aylara göre değişen (artan) sıcaklık ve nem etkisi ile laktasyon dönemlerinin ilerlemesine yorumlanabilir (Margatho ve ark., 2018; Sandrucci ve ark., 2019). Koop ve ark., (2010) ve Jimenez Granado ve ark., (2014) ise laktasyonun son döneminde süt veriminin azalmasına bağlı olarak sütte azalan kuru madde oranının SHS'nda artışa neden olduğunu bildirmişlerdir.

SHS'ye örnek alınan işletmelerin etkisi önemli $(P<0.05)$ bulunmuştur. İşletme etkisinin sürülere göre değişen; sağım öncesi ve sonrasında uygulanan hijyen yöntemi, sağım sonrası sütün bekletilme süresi vb gibi idari uygulamalardan kaynaklandığı değerlendirilmiştir.

İşletmelere göre somatik hücre sayılarının geometrik ortalamalarının değişimi Şekil 2'de verilmiştir. İşletmelere göre en düşük ve en yüksek geometrik ortalamalar 572756.5 hücre-ml ve 1324806 hücre $^{-m l}$, genel ortalama ise 728894.37 hücre ${ }^{-m l}$ olarak tesbit edilmiştir.

Buna göre 20 keçi sürüsünden 19'unda (\% 95) tank SHS değeri $A B$ otoriteleri tarafından (Barbosa ve ark., 1994) önerilen $1.5 \times 10^{6}$ cells $^{-\mathrm{ml}^{\prime}}$ den düşüktür. Tüm işletmelerde elde edilen geometrik SHS ortalamaları gerek ABD'de keçiler için bildirilen üst sınır değerinden, gerekse Uluslararası Küçükbaş ruminantlar süt ve somatik hücre sempozyumunda (Barbosa ve ark., 1994), $A B$ otoriteleri tarafından önerilen $1.5 \times 10^{6}$ cells $^{-m^{\prime}}$ değerinden düşüktür.

Sürüler dikkate alınmaksızın yapılan değerlendirmede ise alınan 96 örnekten 91 tanesinde (\% 95) tank SHS değeri $A B$ otoriteleri (Barbosa ve ark. 1994) tarafından önerilen $1.5 \times$ $10^{6}$ cells $^{-\mathrm{ml}^{\prime}}$ den düşüktür.

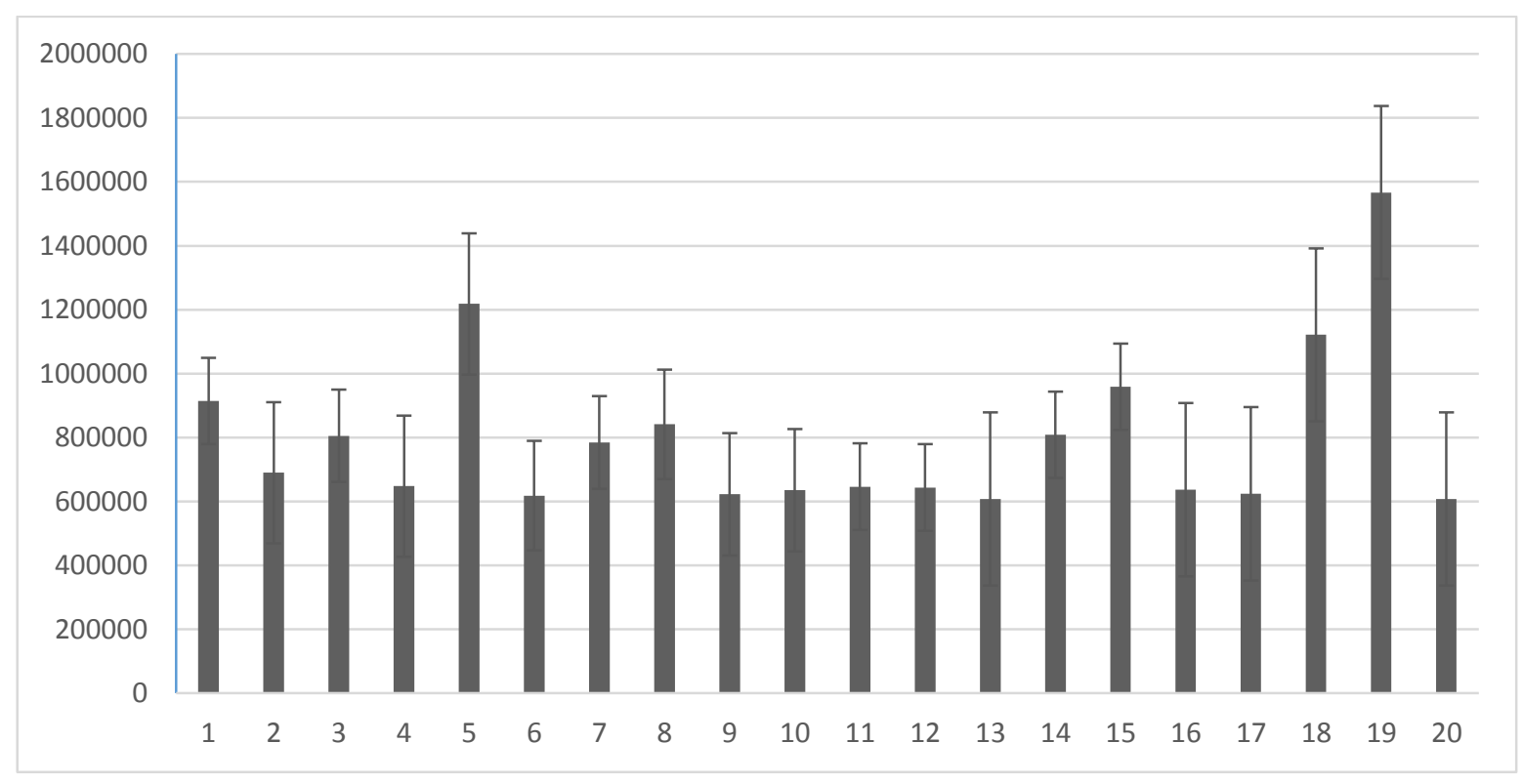

Şekil 2. İşletmelere göre somatik hücre sayıları

Figure 2. Somatic cell count according to herds

SHS takibi, tespiti ve değerlendirilmesi, sürü ve hayvanın meme sağlığı ile ilgili bilgi vermesi açısından önemlidir. Zira sütçü hayvanlarda memedeki enfeksiyon şiddeti arttıkça somatik hücre sayısı da yükselmektedir. SHS'nın yüksek olması süt ürünlerinin işlenmesi sırasında problemlere neden olabilmekte, özellikle de peynir veriminde düşüşe neden olmaktadır. Bu sebeple, koyun ve keçi sütü ve süt ürünlerinin kalitesini arttırmak için SHS'nın azaltılmasını amaçlayan programların uygulanmasına esas olmak üzere bu populasyonlarda zaman zaman gerek hayvan bazında ve gerekse sürü düzeyinde somatik hücre düzeyleri ölçülmelidir.

$\mathrm{Bu}$ çalışmada, elde sağım yapılan keçi işletmelerinde $S H S^{\prime}$ ıı $A B$ otoriteleri tarafından önerilen değerlerden düşük olduğu saptanmıştır. Daha büyük sürülerde entansif üretim ile makinalı sağıma geçilmesi ve sağılan sütün daha kısa sürede alıcı işletmelere ulaştırılması durumunda sütteki somatik hücre sayısının daha da azalacağı söylenebilir. 
Ekler

Bu çalışma Kahramanmaraş Sütçü İmam Üniversitesi Bilimsel Araştırma Projeleri Yönetim Birimi (2020/1-21 M) tarafından desteklenmiştir. Makale yazarı verilerin toplanmasına izin veren Gaziantep Damızlık Koyun Keçi Yetiştiricileri Birliği yönetimine teşekkür ederler.

Çıkar Çatışması Beyanı: Makale yazarı, sonuçları veya yorumları etkileyebilecek herhangi bir maddi veya diğer asli çıkar çatışması olmadığını beyan eder.

\section{Kaynaklar}

Anonim (1992). Council Directive 92/46/EEC. https://eurlex.europa.eu/legal-content/EN/TXT/PDF/?uri= CELEX:01992L0046-20040501\&from=EN

Anonim (2019a). Türk Gıda Kodeksi Çiğ Süt ve Isıl iş̧lem Görmüş İçme Sütleri Tebliği (Tebliğ No: 2000/6). https://www.resmigazete.gov.tr/arsiv/23964.pdfErişi m Tarihi: 30.09 .2020

Anonim (2019b). US Food\&Drug Administration, https://www.fda.gov/media/114169/ download. Erişim Tarihi: 30.09 .2020

Arias, R., Oliete, B., Ramon, M., Arias, C., Gallego, R., Montoro, V., Gonzalo, C \& Perez, M.D. (2012). Longterm study of environmental effects on test-day somatic cell count and milk yield in Manchega sheep. Small Ruminant Research, 106(1), 92- 97/ https://doi.org/10.1016/j.smallrumres.2012.03.019

Barbosa, M., Barillet, F., Berthelot, X., Casu, S., Foglini, A., Gabi-A, AD., Kalantzopoulos, G., Ledda, A., Perrin, G., Poutrel, B., Renaud, J \& Rubino, R. (1994). Conclusioni delcomitato Scientfico International Symposium: Somatic Cells and Milk of Small Ruminants, Italia.

Barrón-Bravo, O. G., Gutiérrez-Chávez, A. J., Ángel-Sahagún, C. A., Montaldo, H. H., Shepard, L \& Valencia-Posadas, M. (2013). Losses in milk yield, fat and protein contents according to different levels of somatic cell count in dairy goats. Small Ruminant Research, 113(23), 421-431/ https:// doi.org/ 10.1016/ j.small rumres.2013.04.003

Berry, E., \& Broughan, J. (2007). Use of the DeLaval cell counter (DCC) on goats' milk. Journal of Dairy Research, 74(3), 345-348/https:77/doi:10.1017/ S0022029907002592

Corrales, J. C., Sanchez, A., Luengo, C., Poveda, J. B., \& Contreras, A. (2004). Effect of clinical contagious agalactia on the bulk tank milk somatic cell count in Murciano-Granadina goat herds. J Dairy Sci, 87(10), 3165-3171/ https://doi.org/10.3168/jds.S00220302(04)73451-7

Droke, E. A., Paape, M. J., \& Di Carlo, A. L. (1993). Prevalence of high somatic cell counts in bulk tank goat milk. $J$ Dairy Sci, 76(4), 1035-1039/ https://doi.org/10.3168/
jds.S0022-0302(93)77431-7

Griffiths, M. W. (Ed.). (2010). Improving goat milk: Improving the Safety and Quality of Milk: Improving quality in milk Products. Elsevier.

Gonzalo, C., Linage, B., Carriedo, J.A., Fuente, F. de la \& San Primitivo, F. (2006). Evaluation of the Overall Accuracy of the DeLaval Cell Counter for Somatic Cell Counts in Ovine Milk. J Dairy Sci, 89(12), 4613-4619/ https://doi.org/10.3168/jds.S0022-0302(06)72511-5

Jimenez-Granado R., Sanchez-Rodriguez M., Arce C \& Rodriguez-Estevez V. (2014). Factors affecting somatic cell count in dairy goats: a review. Spanish $J$. Agric. Res., 12, 133-150/ 10.5424/sjar/2014121-3803

Koop, G., Van Werven, T., Schuiling, HJ \& Nielen M. (2010). The effect of subclinical mastitis on milk yield in dairy goats. J Dairy Sci. 93(12), 5809-5817/ https:// doi. org/10.3168/jds.2010-3544

Luengo, C., Corrales, J. C., Saachez, A., \& Contreras, A. (1999). Daily variation in somatic cell counts from bulk tank goat milk. Publication-European Association For Animal Production, 95, 188-191/

Luengo, C., Sánchez, A., Torres, A., \& Contreras, A. (2001). Variation through the first half of lactation in bulk tank somatic cell counts for Murciano-Granadina goats. R.(. Rubino, \& P.(. Morand-Fehr, Production systems and product quality in sheep and goats (Options Méditerranéennes: Série A. Séminaires Méditerranéens: n. 46)(pp. 93-96). Zaragoza: CIHEAM. URL: http://ressources. ciheam. org/om/pdf/a46/01600117. pdf.

Marcinkoniene, L \& Ciprovica, I. (2020). The influence of milk quality and composition on goat milk suitability for cheese production. Agronomy Research, 18 (Special Issue 3), 1796-1703/ https://doi.org/10.15159/ar. 20.094

Margatho, G., Rodríguez-Estévez, V., Medeiros, L., \& Simões, J. (2018). Seasonal variation of Serrana goat milk contents in mountain grazing system for cheese manufacture. Rev. Med. Vet, 169, 157-165.

Mehdid, A., Martí-De Olives, A.M.-D., Fernández, N., Rodríguez, M \& Peris, C. (2019). Effect of stress on somatic cell count and milk yield and composition in goats. Research in Veterinary Science, 125, 61-70/ https://doi.org/10.1016/j.rvsc.2019.05.015

Orhan, H., Efe, E \& Şahin, M. (2004). SAS Yazılımı ile İstatistiksel Analizler. Isbn : 975-270-435-2. Tuğra Ofset, Isparta, $139 \mathrm{pp}$.

Paape, M. J., Poutrel, B., Contreras, A., Marco, J. C., \& Capuco, A. V. (2001). Milk somatic cells and lactation in small ruminants. I Dairy Sci, 84, E237-E244/ https://doi.org/10.3168/jds.S0022-0302(01)70223-8

Paape, MJ., Wiggans, GR., Bannerman, DD., Thomas, DL., Sanders, AH., Contreras, A., Moroni, P \& Miller RH. (2007). Monitoring goat and sheep milk somatic cell counts. Small Ruminant Research, 68(1-2), 114-125/ https://doi.org/ 10.1016/ j.smallrumres.2006.09.014

Paschino, P., Giuseppe, M., V., Dettori, M., L \& Pazzola, M. (2019). An approach for the estimation of somatic cells' effect in Sarda sheep milk based on the analysis of milk traits and coagulation properties. Small Ruminant Research, 171, 77-81/https://doi.org/ 10.1016/j.smallrumres.2018.10.010 
Persson, Y \& Olofsson I. (2011). Direct and indirect measurement of somatic cell count as indicator of intramammary infection in dairy goats. Acta Vet Scandin. 53(1), 1-5/ https://doi:10.1186/1751-014753-15

Raynal-Ljutovac, K., Pirisi, A., De Cremoux, R \& Gonzalo C. (2007). Somatic cells of goat and sheep milk: analytical, sanitary, productive and technological aspects. Small Ruminant Research, 68(1-2), 126-144/ https://doi.org/10.1016/j.smallrumres.2006.09.012

Rupp, R., Clement, V., Piacere, A., Robert-Granie, C \& Manfredi E. (2011). Genetic parameters for milk somatic cell score and relationship with production and udder type traits in dairy Alpine and Saanen primiparous goats. J Dairy Sci. 94(7), 3629-3634/ https://doi.org/10.3168/jds.2010-3694

Sandrucci, A., Bava, L., Tamburini, A., Gislon, G., \& Zucali, M. (2019). Management practices and milk quality in dairy goat farms in Northern Italy. Italian Journal of Animal Science, 18(1), 1-12/DOI: 10.1080/1828051X. 2018.1466664.
Souza, FN., Blagitz, MG., Penna, CFAM., Della Libera, AMMP., Heinemann, MB \& Cerqueira MMOP. (2012). Somatic cell count in small ruminants: friend or foe. Small Ruminant Research, 107(2-3), 65-75/ https://doi.org/10.1016/j.smallrumres.2012.04.005

Stuhr, T., Aulrich, K., Barth, K., Knappstein, K \& Larsen T. (2013). Influence of udder infection status on milk enzyme activities and somatic cell count throughout early lactation in goats. Small Ruminant Research, 111(1-3), 139-146/ https://doi.org/ 10.1016/ j.smallrumres.2012.09.004

Sutera, A.M., Portolano, B., Gerlando, R., Sardina, M., T., Mastrangelo, S \& Tolone, M., 2018, Determination of milk production losses and variations of fat and protein percentages according to different levels of somatic cell count in Valle del Belice dairy sheep. Small Ruminant Research 162(1), 39-42/ https://doi.org/10.1016/ j.smallrumres. 2018.03.002. 